\title{
In vitro Evaluation of Bacterial Bioagents against Fusarium wilt of Banana caused by Fusarium oxysporum f. sp. Cubense
}

\author{
T. C. Archith ${ }^{1} *$, V. Devappa ${ }^{2}$ and R. K. Mesta ${ }^{1}$ \\ ${ }^{1}$ Department of Plant Pathology, College of Horticulture, Bagalkot-587104, Karnataka, India \\ ${ }^{2}$ Department of Plant Pathology, College of Horticulture, Bengaluru-560065, Karnataka, \\ India \\ *Corresponding author
}

\section{A B S T R A C T}

The present investigation was undertaken to evaluate potential inhibitory effect of indigenous bacterial biocontrol agents against Fusarium oxysporum f. sp.

\section{Keywords}

Fusarium wilt,

Banana,

Pseudomonas

fluorescens,

Bacillus subtilis

Article Info

Accepted:

12 March 2021

Available Online:

10 April 2021 cubense, a causal organism of wilt disease in Banana crop. Twelve indigenous bacterial bioagents were isolated from banana rhizosphere soil collected from banana growing fields in and around Mysore, Mandya and Chamarajanagar districts, which is geographically located in Southern part of Karnataka, India. In PCR identification, 16S rDNA test, the size of the amplicon was $360 \mathrm{bp}$ and $450 \mathrm{bp}$ in Bacillus spp. and Pseudomonas spp. Amongst six isolates of Pseudomonas spp, and six isolates of Bacillus spp showed significant inhibition against the test pathogen. Among all the Pseudomonas isolates tested, Isolate MPB-2 (Pseudomonas fluorescens) showed maximum inhibition of 38.89 per cent and Bacillus sp CKB-1 showed maximum inhibition of 33.89 per cent. The obtained preliminary results are useful and promising enough for further studies towards isolation and characterization of bacterial bioagents responsible for disease control.

\section{Introduction}

Banana (Musa spp.) is an important ancient tropical fruit in the world. It belongs to family Musaceae and native to tropical region of Southeast Asia. Banana is cultivated throughout the warm tropical regions of the world and extensively cultivated in Brazil,
Ecuador, China, Philippines, Indonesia, Cost Arica, Mexico, Thailand, Colombia and India. It is grown as monoculture or mixed cropping system. The total annual global production of banana is estimated around 113.9 million tonnes (agriexchange.apeda.gov.in). India stands first in the world banana production ( $26.5 \%$ of the world production). In India, it 
is regarded as "fruit of the wise men" and it is grown in an area of 8.74 lakh ha with an annual production of 30 million tones and the average productivity is $35.88 \mathrm{MT} / \mathrm{ha}$ (http://agricoop.nic.in). Tamil Nadu state has the largest area under cultivation in India, followed by Maharashtra, Gujarat, Andhra Pradesh, and Karnataka. The average yield/hectare is very low, due to abiotic stressors, such as salinity (Willadino et al., 2017) and drought (Said et al., 2015; Nansamba et al., 2020). Another biotic stressor, represented by their primary pests, the banana root borer (Cosmopolites sordidus) and the nematodes Meloidogyne spp., Pratylenchus coffeae and Radopholus similis (Monteiro et al., 2020) and disease-causing pathogens, including banana bunchy top virus (BBTV) (Galvez et al., 2020; Sairam et al., 2020), Xanthomonas vasicolap.v.musacearum causing bacterial wilt (Studholme et al., 2020), Pseudocercospora fijiensis causing black Sig Sigatoka (Timm et., 2016) and Fusarium oxysporum f. sp. cubense (FOC) causing Fusarium wilt (Dita et al., 2018). Among, Panama disease also known as Fusarium wilt or vascular wilt incited by Fusarium oxysporum f. sp. cubense (E.F. Smith) Snyd. and Hans. is one of the world's most disastrous plant diseases (Siamak and Zheng, 2018) and the disease was believed to have originated in Southeast Asia (Stover, 1962) The latest outbreak of FocTR4 has been confirmed in the Americas affecting the most popular commercial variety which could have jeopardized banana production for decades (Lambert, 2019). Fusarium oxysporum f. sp. cubense (Foc) causes a typical wilt syndrome on the infected banana plants accompanied by the necrosis and rotting of roots, rhizome, and pseudostem vessels. These symptoms occur between 2 and 5 months after infection of roots (Stover, 1962). The first internal symptom of the disease occurs in the hair roots which are the initial sites of infection. The infection later progresses to the rhizome and pathogen passes through the affected vessels to the new growing shoot $(\mathrm{Li}$, et al., 2017). Use of pesticides and other commercially available fungicides have shown a ray of hope on improving the crop yield but at the same time, the large use of these pesticides and fungicides are bound with various limitations such as loss of soil fertility, contamination of both ground and surface water, biomagnifications, health hazards, etc. which are reported to have deleterious effects on health of all living organisms of the biosphere. Therefore, alternative strategies are being widely employed. One such practice is use of bio-control agents. Research on biocontrol agents have expanded in recent past as eco-friendly management of targeted crops. One such area is bio-control activity against Fusarium wilt Banana. Hence, the present study was designed and executed towards isolation of indigenous bio-control isolates of Pseudomonas spp and Bacillus spp from Banana rhizosphere soil as the performance of the introduced bio-control agent may not be always favourable because of competition for space and resources with the already established microorganism in the microcosm. Literature pursued by far have demonstrated positive ray of bio-control agents against Fusarium wilt but there is a lack of research dealing with the species used in the study and its commercial application. Consequently, large number of studies demonstrated the potent of isolates bearing significant activity even at harsh conditions (Killani et al., 2011).

\section{Materials and Methods}

\section{Isolation of native antagonistic rhizosphere bacteria}

Antagonistic bacteria were isolated by serial dilution technique. Composite soil sample was collected from rhizosphere of healthy plants. The soils were dried under shade and then used for serial dilution. To get $10^{-1}$ dilution, 
ten grams of soil was dissolved in $90 \mathrm{ml}$ of sterile distilled water. From this, one $\mathrm{ml}$ of soil suspension was taken and added to nine $\mathrm{ml}$ of sterile distilled water to get $10^{-2}$ dilution. This was repeated until a final dilution of $10^{-6}$ for bacteria was obtained. Antagonistic bacteria were isolated on King's B agar medium and LB agar medium by using a dilution of $10^{-6}$.

One $\mathrm{ml}$ of final dilution of soil suspension was poured into sterilized Petri plates, and then melted and cooled media was poured. Plates were rotated gently on the laminar air flow bench to get uniform distribution of soil suspension in the medium. Subsequently the plates were incubated at $28 \pm 2{ }^{\circ} \mathrm{C}$ and observed at frequent intervals for the development of colonies. One day old individual colonies of gram-negative rodshaped bacteria on $\mathrm{KB}$ agar medium and gram-positive rod shaped on LB agar medium were picked up and purified by streak plate method and stored in NA slants at $4^{\circ} \mathrm{C}$ for further use.

\section{Identification of Bioagents and In vitro evaluation of antagonistic potential of biological control agents}

The bacterial bioagents were identified using the molecular tools. Confirmed bioagents by PCR is used the in vitro studies. Total of 12 bioagents was tested against Fusarium oxysporum f. sp. cubense in dual culture technique.

Among them, six isolates were Bacillus spp and six were Pseudomonas spp. The mycelial disc $(5 \mathrm{~mm})$ from 7 days old culture of Fusarium was placed on one side of the plate containing PDA medium, one day prior to bacterial streaking and then next day antagonist bacterial strains were streaked on the opposite side of the plate with the help of sterilized inoculation needle. The plates were incubated at room temperature for seven days.
The inhibitory effects of bacterial against linear growth of Fusarium are determined. Per cent inhibition of mycelial growth of test pathogen over control was calculated by the formula.

\section{Per cent inhibition \\ $=\frac{\text { Control }- \text { Treatment }}{\text { Control }} \times 100$}

\section{Statistical analysis}

The data obtained in the experiment were statistically analyzed by using completely randomized design (CRD). The data pertaining to percentages were arc sin transformed using Web Agri. Stat. Package 2 developed by ICAR research complex, Goa. The significance of the effect of Pseudomonas and Bacillus on growth characteristics were determined by the magnitude of the $\mathrm{F}$ value $(\mathrm{P}$ $=0.01)$. Results of the experiment were analyzed following appropriate statistical methods as per the procedure suggested by Panse and Sukhatme (1985).

\section{Results and Discussion}

All the bacterial bioagents were isolated using serial dilution method, initial identification of Pseudomonas and Bacillus species were made using morphological features. Typical colony of Pseudomonas spp. showed umbonate, round smooth margins, and appear colourless, translucent on King's B medium and fluorescent when exposed to UV light.

Bacillus appeared as dry, flat, irregular creamy colony with irregular lobate margins. Based on the morphological appearance and colony characters, total six Pseudomonas species and six Bacillus species were selected from soil samples. All the isolates were stored in a glycerol stock $(25 \%)$ at $-80{ }^{\circ} \mathrm{C}$. The isolates were subjected to $16 \mathrm{~S}$ rDNA test of prokaryotes (16s rDNA region). 
Table.1 In vitro evaluation of bacterial bioagents against Fusarium oxysporum f. sp. cubense using dual culture method

\begin{tabular}{|c|c|c|c|}
\hline $\begin{array}{l}\text { SI. } \\
\text { No. }\end{array}$ & Isolate No. & $\begin{array}{l}\text { Radial growth of } \\
\text { Fusarium in dual } \\
\text { culture* }(\mathrm{cm})\end{array}$ & $\begin{array}{l}\text { Per cent inhibition of } \\
\text { mycelia growth over } \\
\text { control }(\%)\end{array}$ \\
\hline 1 & MNB - 2(Pseudomonas) & 6.75 & $25.00(30.00)$ \\
\hline 2 & MNB - 3(Pseudomonas) & 6.65 & $25.81(30.53)$ \\
\hline 3 & MNB - 4(Pseudomonas) & 7.12 & $20.89(27.19)$ \\
\hline 4 & CCB - 2(Pseudomonas) & 6.53 & $27.40(31.56)$ \\
\hline 5 & CKB - 2(Pseudomonas) & 8.50 & $5.56(13.63)$ \\
\hline 6 & MPB - 2(Pseudomonas $)$ & 5.56 & $38.25(38.20)$ \\
\hline 7 & MNB - 1(Bacillus $)$ & 7.50 & $16.67(24.09)$ \\
\hline 8 & CCB - 1(Bacillus) & 6.12 & $32.00(34.44)$ \\
\hline 9 & MHB - 1(Bacillus $)$ & 6.95 & $22.78(28.50)$ \\
\hline 10 & CKB - 1(Bacillus $)$ & 5.95 & $33.89(35.60)$ \\
\hline 11 & MMB - 1(Bacillus) & 6.83 & $24.11(29.40)$ \\
\hline 12 & MPB - 1(Bacillus) & 6.25 & $30.56(33.56)$ \\
\hline \multirow[t]{3}{*}{13} & Control & 9.00 & - \\
\hline & S. Em \pm & 0.067 & \\
\hline & CD $(1 \%)$ & 0.264 & \\
\hline
\end{tabular}

Plate.1a PCR amplification of 16s regions of Bacillus spp. On 1.2\% agarose gel. Amplification exactly at 360bp confirms the organism as Bacillus spp.

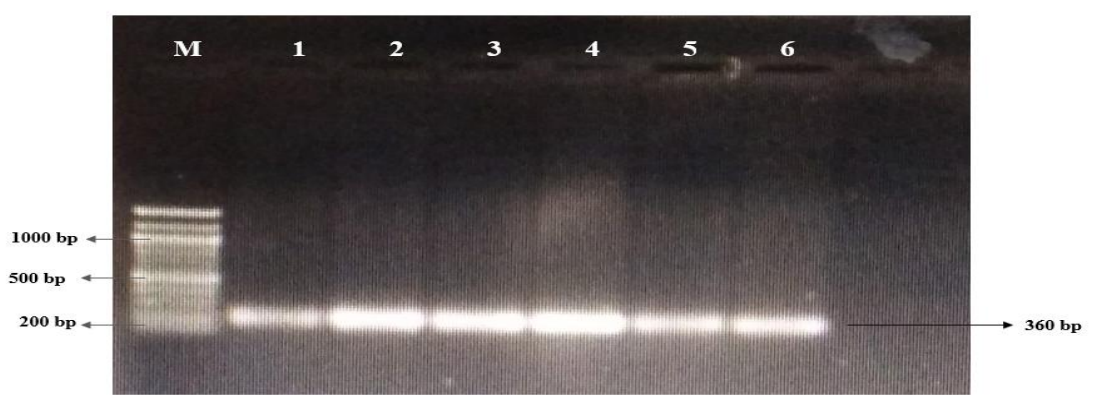


Plate.1b PCR amplification of 16s regions of Pseudomonas spp. On $1.2 \%$ agarose gel. Amplification exactly at 450 bp confirms the organism as Pseudomonas.

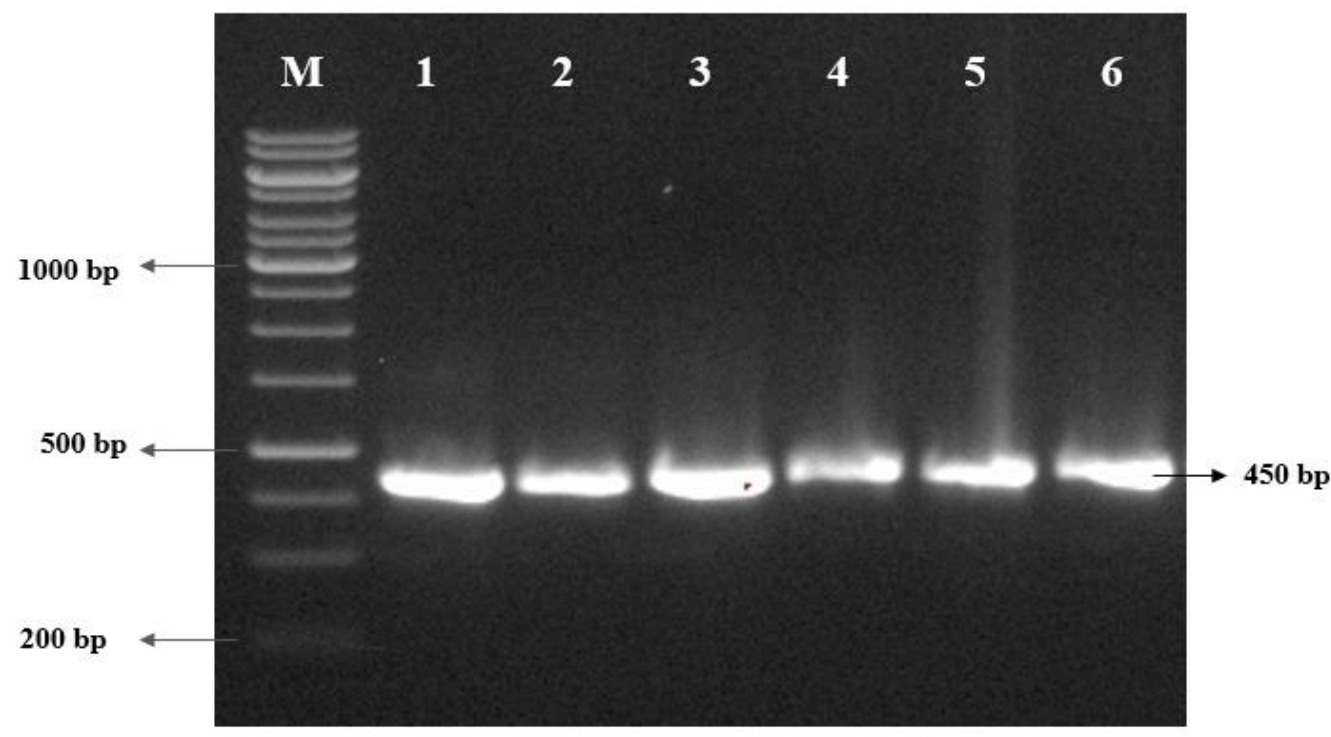

Plate.2a In vitro evaluation of antagonistic potential of Pseudomonasisolates against Fusariumoxysporum f. sp.cubense
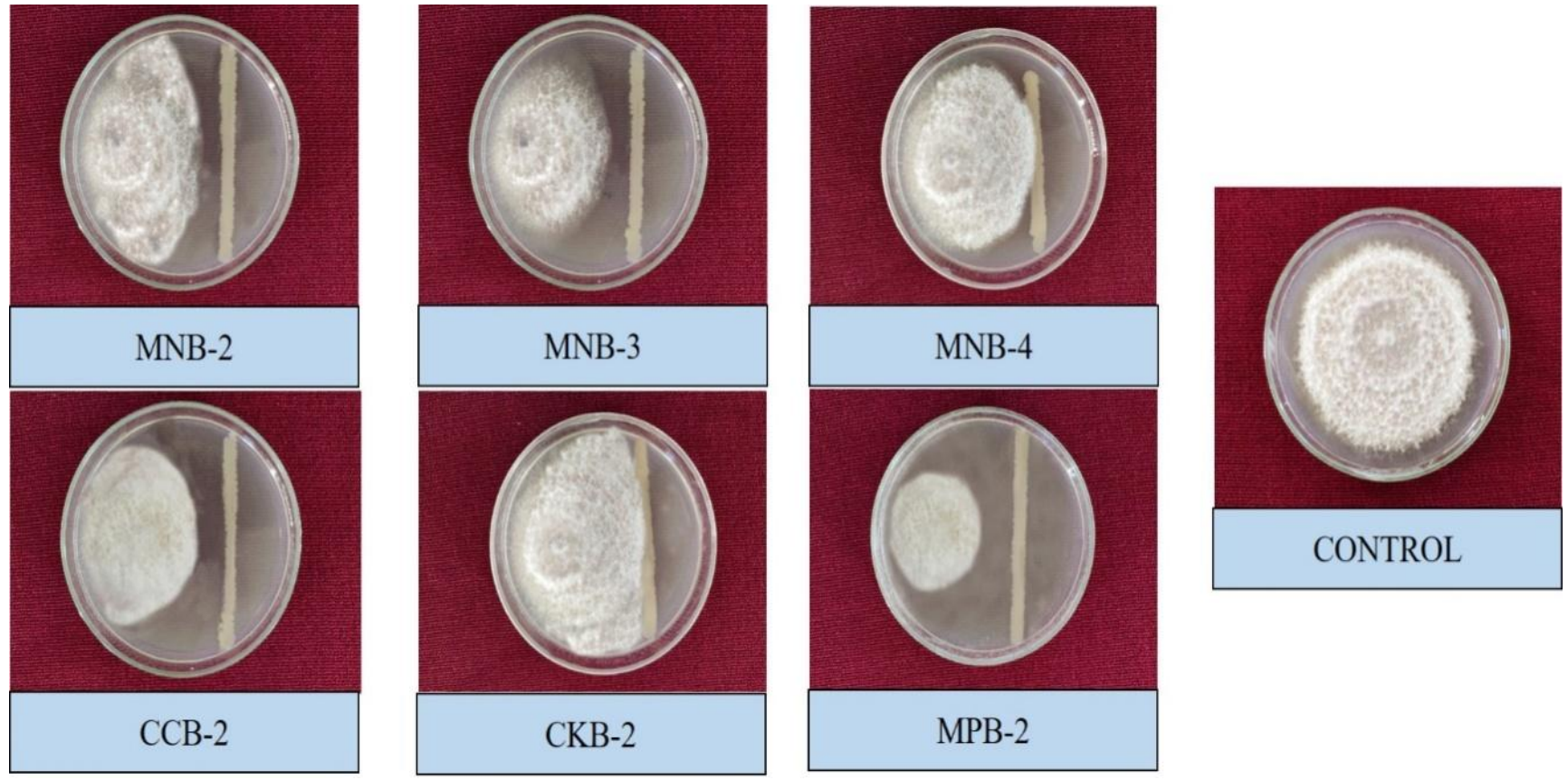
Plate.2b In vitro evaluation of antagonistic potential of Bacillus isolates against Fusarium oxysporum f. sp.cubense
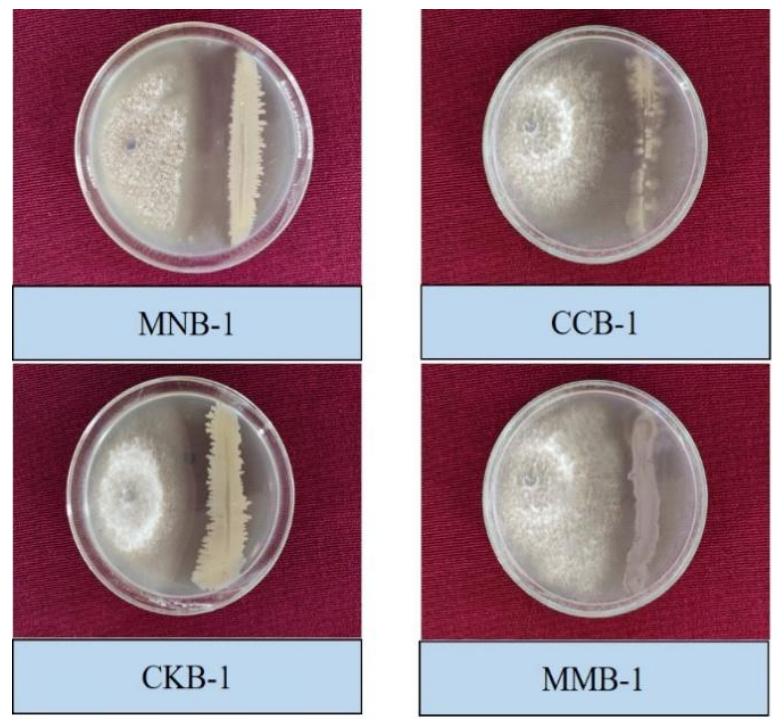

PCR amplification was observed in all the twelve isolates during $16 \mathrm{~S}$ rDNA test with the amplicon size of approximately $360 \mathrm{bp}$ and $450 \mathrm{bp}$ in Bacillus spp. (Plate 1a) and Pseudomonas spp.(Plate 1b), thus the isolates were confirmed as Pseudomonas spp. and Bacillus spp. The antagonistic effect of six biocontrol agents were evaluated against Fusarium oxysporum f. sp. cubense and the results are presented in Table 1. All the in vitro evaluation of Pseudomonas spp. against Fusarium oxysporum f. sp. cubense growth is represented in the Table 1 and Pate 2a. Analysis of antagonistic activity of isolated bioagents showed significant difference among the isolates collected. Maximum inhibition was observed in MPB-2 (38.89\%), followed by CCB-2 (27.78 \%), MNB-3 (26.11 $\%), \mathrm{MNB}-2(25.00 \%)$ and MNB - 4 (20.89 $\%)$. The lowest inhibition zone was observed in CKB - $2(5.56 \%)$. Bacillus spp. also recorded various zone of inhibition against Fusarium oxysporum f. sp. cubense under in vitro condition. Among the isolates CKB-1 showed maximum inhibition of 33.89 per cent followed by CCB-1 (32.00 \%), MPB-1 (30.56 $\%)$, MMB-1(24.11\%), MHB-1 (22.78\%) and the least zone of inhibition was observed in
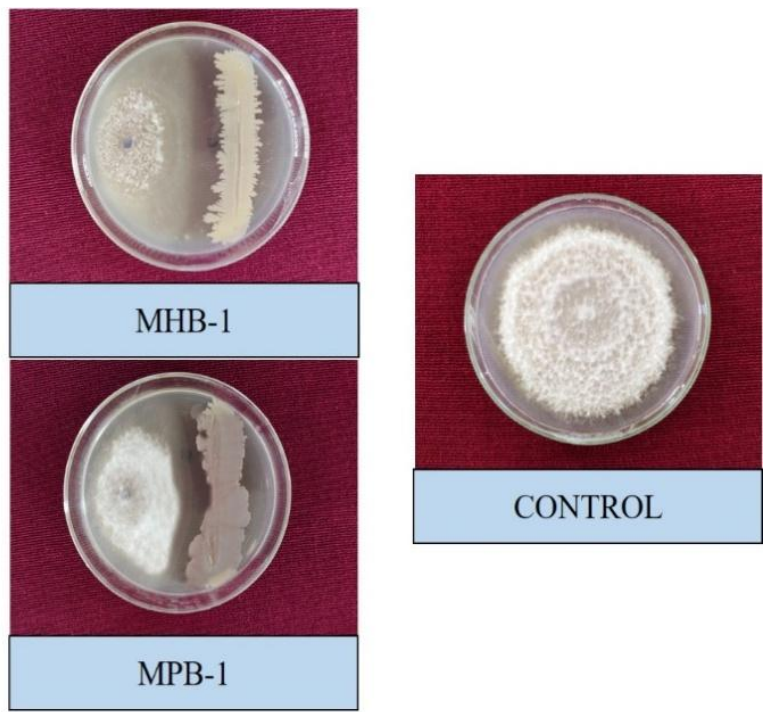

MNB-1 (16.67 \%). Zone of inhibition produced by the bioagents were documented (Plate 2b). The results were supported by Saravanan et al., (2004) who conducted the study to know the efficacy of Pseudomonas fluorescens on Fusarium wilt pathogen in banana rhizosphere. All the strains of Pseudomonas fluorescens isolated from banana rhizosphere had significant inhibitory action on the growth of Fusarium oxysporum f. sp. cubense.

Among the strains Pfm of Pseudomonas fluorescens had higher inhibitory action than other strain. Similarly, Killani et al., (2011), who reported that Bacillus subtilis successfully inhibited the growth of all the soil borne fungal pathogens isolated from cowpea in vitro. Shobha and Kumudini, 2012 showed Bacillus isolates-controlled $F$. oxysporum growth irrespective of the antagonistic method used. Bacterial bio agents are the promising alternative strategies for management of Fusarium wilt. As far the results demonstrated the positive ray of bio-control agents against Fusarium wilt. The potent of the current isolates showed some extent of inhibition indicting a need of screening more beneficial 
bacteria for obtaining significant effect against the pathogen.

\section{Acknowledgement}

I'm thankful to Department of Plant Pathology, University of Horticulture Science, Bagalkot, Karnataka, India.

\section{References}

Dita, M., Barquero, M., Heck, D., Mizubuti, E. S., Staver, C. P., 2018. Fusarium wilt of banana: Current knowledge on epidemiology and research needs toward sustainable disease management. Frontier of Plant Science 9, 1468.

Galvez, L. C., Barbosa, C. F., Koh, R.B., Aquino, V.M., 2020. Loop-mediated isothermal amplification (LAMP) assays for the detection of abaca bunchy top virus and banana bunchy top virus in abaca. Crop Protection 131, 105101.

Killani, A. S., Abaidoo, R. C., Aintokun, A. K. and Abiala, M. A., 2011, Antagonistic effect of indigenous Bacillus subtilis on root-/soil-borne fungal pathogens of Cowpea Researcher, 3:11-18.

Lambert, J., 2019, Alarm as Devastating Banana Fungus Reaches the Americas. Nature News. 1476-468.

Li, C., Yang, J., Li, W., Sun J., 2017, Direct root penetration and rhizome vascular colonization by Fusarium oxysporum $\mathrm{f}$. sp. cubense are the key steps in the successful infection of Brazil Cavendish. Plant Disease 101(12), 2073-2078.

Monteiro, J. D., Santos, M., Santos, J. R. P., Cares, J. E., Marchao, R. L., Amorim, E.P., Costa, D.D., 2020. Identification of plant parasitic nematodes in triploid and tetraploid bananas in brazil. Review of Caatinga33, 865-877.

Nansamba, M., Sibiya, J., Tumuhimbise, R., Karamura, D., Kubiriba, J., Karamura, E., 2020. Breeding banana (Musa spp.) for drought tolerance. A review of Plant Breeding 139, 685-696.

Said, E. M., Mahmoud, R. A., Akshar, R., Safwat, G., 2015. Drought stress tolerance and enhancement of banana plantlets In vitro. Austin Journal of Biotechnology and Bioengineering 2, 1040.

Sairam, S., Selvarajan, R., Handanahalli, S. S., Venkataraman, S., 2020. Towards understanding the structure of the capsid of Banana Bunchy Top Virus. Bio Rxiv, 1-2.

Saravanan, T., Bhaskaran, R. and Muthusamy, M., 2004, Pseudomonas fluorescens Induced Enzymological Changes in Banana Roots (cv. Rasthali) against Fusarium wilt disease. Plant Pathol. J., 3:72-80.

Shobha, G. and Kumudini, B. S., 2012, Antagonistic effect of the newly isolated PGPR Bacillus spp. on Fusarium oxysporum. Int. J. Appl. Sci. Eng. Res., 1:463-474.

\section{How to cite this article:}

Archith, T. C., V. Devappa and Mesta, R. K. 2021. In vitro Evaluation of Bacterial Bioagents against Fusarium wilt of Banana caused by Fusarium oxysporum f. sp. Cubense. Int.J.Curr.Microbiol.App.Sci. 10(04): 463-469. doi: https://doi.org/10.20546/ijcmas.2021.1004.048 